\title{
Production performance of Pabda (Ompok pabda) and Gulsha (Mystus cavasius) with Rohu (Labeo rohita) in natural pond conditions
}

\author{
PARVEZ CHOWDHURY*, ANURADHA BHADRA AND AFM SHOFIQUZZOHA \\ Bangladesh Fisheries Research Institute, Mymensingh 2201, Bangladesh \\ *Email: nitoldhk@gmail.com
}

\begin{abstract}
The study was carried out infourselected farmer's pond in Netrokona sadarand Barhatta upazillas (sub district) under Netrokona district during April to September 2019 having average pond area of 0.14 ha each. The ponds were prepared by removing aquatic vegetation and unwanted fish and other animals, and applying with lime at the rate of $250 \mathrm{~kg} / \mathrm{ha}$. Five days after liming, water was supplied from shallow tube well to the ponds and filled up to the depth of $1.5 \mathrm{~m}$. The fry of Pabda (Ompok pabda) and Gulsha (Mystus cavasius) with Rohu (Labeo rohita) were stocked at the rate of 175000; 87,500 and 2000/ha, respectively. After stocking, fish were fed at a rate of $5-12 \%$ of body weight with supplementary feed $(30 \%$ crude protein). Fish sampling were done at monthly interval to know the fish growth status and also to adjust feed ration. After six months rearing, fish were harvested by repeated seine netting. Total bulk weight and number of fish from each pond was recorded. Survival and gross production of fish of each pond were estimated. The harvesting weight of pabda ranged from 33 to $36 \mathrm{~g}$. While the harvesting weight of Gulsha and Rohu ranged from 26-27g and 591-614g, respectively. Based on the number of fish harvested at the end of the experiment, survival ranged from 75 to $88 \%$.Total production of Pabda (O. pabda) and Gulsha (M. cavasius) with Rohu was estimated at 5202, 1772 and $1066 \mathrm{~kg} / \mathrm{ha}$, respectively. The total production of fish as recorded in trial ponds were $8043 \mathrm{~kg} / \mathrm{ha}$.

Keyword: Ompok pabda, Mystus cavasius, Labeo rohita, Polyculture
\end{abstract}

\section{Introduction}

Fish and fisheries play significant roles in thenational economy such as nutrition, income generation, and employment and foreign exchange earnings of Bangladesh. The protein problem can be reduced by increasing the fish production through modern and scientific fish culture and management practice. Modern fish culture means improvement of culture practices through adopting different measures such as proper doses of fertilizer, regular feeding, optimum stocking density, maintenance of the physico-chemical parameters of pond water, prevention of diseases and various control measures. For successful aquaculture, knowledge on several factors is very important among which stocking density of different fish species also plays a vital role in the growth of fish. Higher density of species may affect the growth of another species similarly lower density of a species may reduce the overall production (Sharmin et al. 2019).

Pond aquaculture in Bangladesh is expanding very fast. Currently aquaculture production accounts for about one third of the total fish production in Bangladesh. To increase the production of fish, species selection is very important(Parvez et al. 2019).According to FAO report, Bangladesh ranked $3^{\text {rd }}$ in inland open water capture production and $5^{\text {th }}$ in world aquaculture production (DoF 2019). To increase the suitable indigenous fish species production, species selection is very important. Pabda (Ompok pabda) and Gulsha (Mystus cavisus) are 
integral components of subsistence fisheries for thousands of years but has gained popularity in very recent years. Pabda and Gulsha are better performing species in the pond aquaculture system of Bangladesh. These two fishes are great favorite to consumers because of theirmouthwatering taste and therefore have a great demand andhigh price in the fish market.Though these two species have been reported quite favourable under standard conditions of carp farming (Kohinoor et al. 1997), their culture technique with carps in polyculture system is still under developed. This trial was designed to evaluate the production performances of Rohu (Labeorohita) with Pabda (O. pabda) and Gulsha (M. cavasius) in polyculture management at on farm condition.

\section{Material and Methods}

Experimental ponds: Four ponds of 4 farmers in Netrokona sadar and Barhatta upazillas (subdistrict) under Netrokona district were used during April to September 2019. The average of pond area was 0.35 acre each. The ponds were free from predatory animals, unwanted fishes and aquatic higher vegetation. Flexible plastic pipes were used for water supply from the deep tube-well. The embankment was well protected and covered with grass. Prior to commencing the experiment, rotenone $(12.50 \mathrm{~kg} / \mathrm{ha})$ was applied to eradicate predators and small fish. Then ponds were treated with lime at the rate of $250 \mathrm{~kg} / \mathrm{ha}$.

Stocking of fish and feeding: The fingerlings of Pabda (O. pabda) and Gulsha (M. cavasius) with Rohu (L. rohita) were stocked at the stocking density of $175000 ; 87,500$ and 2000/ha, respectively. The fingerlings of Pabda, Gulsha and Rohu were stocked on 01 April 2019. The fingerlings were fed at the rate of $12 \%$ of their body weight for the first two weeks and it was reduced to $3 \%$ on the subsequent monthstwice daily at $7.0 \mathrm{pm}$ and $6.0 \mathrm{am}$. During the culture trail, lime and salt were applied in all the ponds fortnightly interval at the rate of 50 and 100 $\mathrm{kg} / \mathrm{ha}$, respectively.

Study of water quality parameters: Water transparency of the experimental ponds was measured by a Secchi-disk. Water temperature data were collected from the ponds by using portable thermometer.Dissolved oxygen of water $(\mathrm{mg} / \mathrm{l})$ was measured by portable digital dissolved oxygen (DO) meter (model: DO5509, Lutron, made in Taiwan). $\mathrm{pH}$ was determined by a portable digital $\mathrm{pH}$ meter (Hanna Instruments, Italy, model-H 196107). To determine total alkalinity, samples were collected in $250 \mathrm{ml}$ black plastic bottles and total alkalinity of water samples was determined by titrimetric method using methyl orange indicator.

Fish Sampling and harvesting: Twenty fish of each species from each pond were caught on monthly sampling day using a seine net. After weighted, all fishes were returned into the ponds after sampling. After five months of culture period, fish were harvested by repeated seine netting. After seine netting, the pond water was pumped out and all fishes were harvested. Total bulk weight and number of fish from each pond was recorded.

Data analysis: Data were analyzed using the statistical package, Stat Graphics Version 7. ANOVA was performed on all the dependent variables to find out whether treatments had any significant difference on growth. 


\section{Results and Discussion}

Water quality parameters:Mean values of five months data of each of the parameter are presented in Table I. The water temperature recorded during the study period was more or less similar in different ponds under three treatments. Temperature varied from 32.40 to 34.50 with mean values of $34.05 \pm 1.59,34.11 \pm 2.04,34.50 \pm 7.06$ and $32.40 \pm 1.53^{\circ} \mathrm{C}$ in pond $-1,2,3$ and 4 , respectively (Table I). There were no significant differences among the treatments when ANOVA was performed $(p>0.05)$. Paul (1998) reportedtemperature ranged from 25 to $35^{\circ} \mathrm{C}$ wassuitable for fish culture. Ali (1998) stated that water temperature of ponds remained 20.20 to $36.50{ }^{\circ} \mathrm{C}$ which was favorable to fish culture. In the present experiment water temperature was favorable for fish culture.

Table I. Water quality parameters of the ponds in different ponds

\begin{tabular}{|c|c|c|c|c|}
\hline \multirow[t]{2}{*}{ Parameter } & \multicolumn{3}{|c|}{ Netrokona sadar upazila } & Barhatta upazila \\
\hline & Pond-1 & & Pond-3 & Pond-4 \\
\hline Temperature $\left({ }^{\circ} \mathrm{C}\right)$ & $34.05 \pm 1.59^{\mathrm{a}}$ & $34.11 \pm 2.04^{\mathrm{a}}$ & $34.50 \pm 7.06^{\mathrm{a}}$ & $32.40 \pm 1.53^{\mathrm{a}}$ \\
\hline Transparency $(\mathrm{cm})$ & $33.10 \pm 2.19^{\mathrm{a}}$ & $42.19 \pm 7.55^{\mathrm{a}}$ & $45.40 \pm 1.90^{\mathrm{b}}$ & $39.10 \pm 5.05^{\mathrm{a}}$ \\
\hline $\begin{array}{l}\text { Dissolved oxygen } \\
(\mathrm{mg} / \mathrm{L})\end{array}$ & $5.44 \pm 2.57^{\mathrm{a}}$ & $4.17 \pm 3.13^{b}$ & $4.23 \pm 4.25^{\mathrm{b}}$ & $5.37 \pm 3.17^{b}$ \\
\hline $\mathrm{pH}$ & $8.13 \pm 1.81$ & $7.11 \pm 0.93$ & $7.27 \pm 2.98$ & $7.17 \pm 1.93$ \\
\hline $\begin{array}{l}\text { Total Alkalinity } \\
(\mathrm{mg} / \mathrm{L})\end{array}$ & $153.27 \pm 13.13^{\mathrm{a}}$ & $177.31 \pm 11.77^{b}$ & $164.5 \pm 30.26^{\mathrm{b}}$ & $184.5 \pm 25.20^{\mathrm{b}}$ \\
\hline
\end{tabular}

Water transparency values of different ponds under the treatments showed variations on different sampling dates. The transparency values ranged from 33 to $4 \mathrm{~cm}$ with mean values of transparency were found to be $33.60 \pm 3.19,36.11 \pm 4.55$, and $42.44 \pm 3.90 \mathrm{~cm}$ in pond $-1,2,3$ and 4 , respectively (Table I). Significant differences among the treatments were observed when ANOVA was performed $(p<0.05)$. Transparency values increased with increasing the stocking density of Pabda due to lower abundance of phytoplankton, indicating that Pabda grazed more on plankton. Rahman (1992) stated that the transparency of productive water bodies should be $40 \mathrm{~cm}$ or less (turbidity resulting from plankton). Chowdhury et al. (2018) recorded transparency values ranging from 17 to $34 \mathrm{~cm}$ in tilapia monoculture. The water transparency values of these ponds were within productive range in the present experiment.

The values of dissolved oxygen were found to range from 4.14 to $5.44 \mathrm{mg} / \mathrm{L}$ with mean values of pond $1,2,3$ and 4 were $5.44 \pm 2.57,4.17 \pm 3.13,4.23 \pm 4.25$ and $5.37 \pm 3.17 \mathrm{mg} / \mathrm{L}$, respectively (Table I). The dissolved oxygen concentrations in ponds showed variations among treatments which might be due to variation in the rate of dissolved oxygen consumption by fish and other animals through respiration. However, the fluctuations in dissolved oxygen concentrations in all pond waters within the productive range throughout the experimental period (Boyd 1982). Majumder (2017), Mazid (2009), Sarker (2007) found more or less similar results. In the present experiment the mean dissolved oxygen values were within suitable range. 
PRODUCTION OF PABDA AND GULSHA WITH ROHU IN POND

During the study period, the $\mathrm{pH}$ values of pond water under different treatments were found to be alkaline. The values of dissolved oxygen were found to range from 7.11 to $8.13 \mathrm{mg} / \mathrm{L}$ with mean values of mean values of pond-1, 2, 3 and 4 were $8.13 \pm 1.81,7.11 \pm 0.93,7.27 \pm 2.98$ and $7.17 \pm 1.93 \mathrm{mg} / \mathrm{L}$, respectively (table-1). Different authors have reported a wide variations in $\mathrm{pH}$ from 6.7 to 7.2 (Ahmed 1993); 6.7 to 8.3 (Hossain et al. 1997); 6.5 to 9.0 (Swingle 1967) and 7.18 to 7.24 (Kohinoor et al. 1998) in fertilized fish ponds and found to be productive. The values of $\mathrm{pH}$ recoded in the present experiment are well within above reported ranges, indicating the productive nature of the ponds. The total alkalinity values of the pond water under different treatments were found to be productive level. The values of total alkalinity were found to range from 153 to $184 \mathrm{mg} / \mathrm{L}$ with mean values of pond-1, 2, 3 and 4 were $153.27 \pm 13.13$, $177.31 \pm 11.77,164.5 \pm 30.26$ and $184.5 \pm 25.20 \mathrm{mg} / \mathrm{L}$, respectively. Significant variations ( $p>0.05)$ were observed among the treatments. Majumder et al. (2017) recorded total alkalinity values ranging from 164 to $167 \mathrm{mg} / \mathrm{L}$. Bhuiyan (1970) stated that the total alkalinity of medium productive water ranged from $25-100 \mathrm{mg} / \mathrm{L}$.

Growth and production performances: The average final weights of Pabda, Gulsha and Rohu were $42 \pm 7.80,38 \pm 6.90$ and $33 \pm 7.30 \mathrm{~g}$, in the experimental ponds. The mean values of survival rates in Pond 1, 2, 3 and 4 were 86, 75 and 88\%, respectively. Sultan (1997) obtained survival rates $93.75 \%, 91.88 \%, 86.88 \%$ under treatment-1, treatment- 2 , and under treatment-3 in polyculture of tilapia, rohu, catla and mrigal. In the present experiment average survival rate was comparatively lower of gulsha than otherfish (Table II).

Table II. Growth and production performances of the fish in different ponds

\begin{tabular}{lcccccc}
\hline Fish sp. & $\begin{array}{c}\text { Initial Wt. } \\
(\mathrm{g})\end{array}$ & $\begin{array}{c}\text { Stocking } \\
\text { density/ha }\end{array}$ & $\begin{array}{c}\text { Harvesting } \\
\text { Wt. }(\mathrm{g})\end{array}$ & $\begin{array}{c}\text { Survival } \\
(\%)\end{array}$ & $\begin{array}{c}\text { Species wise } \\
\text { production } \\
(\mathrm{kg} / \mathrm{ha})\end{array}$ & $\begin{array}{c}\text { Total } \\
\text { production } \\
(\mathrm{kg} / \mathrm{ha})\end{array}$ \\
\hline Pabda & $1.80 \pm 0.77$ & 175000 & $35 \pm 3.43$ & 86 & $5206 \pm 16.03$ & $8043 \pm 13.44$ \\
Gulsha & $1.50 \pm 0.80$ & 87500 & $27 \pm 4.22$ & 75 & $1772 \pm 22.65$ & \\
Rohu & $25 \pm 1.31$ & 2000 & $605 \pm 8.35$ & 88 & $1065 \pm 18.28$ & \\
\hline
\end{tabular}

After five months rearing, the production of Pabda, Gulsha and Rohu obtained were $5206 \pm 46.03,1772 \pm 92.65$ and $1065 \pm 88.28 \mathrm{~kg} / \mathrm{ha}$, respectively (Table II). Chowdhury et al. 2019recorded a production from polyculture of Gulsha (M. cavasius) with Rohu ( $L$. rohita) in five months culture period as $5875 \pm 458,7786 \pm 550$ and $8690 \pm 249 \mathrm{~kg} / \mathrm{ha}$ in Treatment 1,2 and 3 , respectively.Kohinoor et al. (1997) recorded an average production from semi-intensive culture of Pabda (O. pabda) with Rajpunti (Barbodes gonionotus) and Mirror carp (Cyprinus carpio) in six months culture period as $2,932 \mathrm{~kg} / \mathrm{ha}$ where the contribution of pabda was only $15.27 \%$, while, Hossain et al. (1998) got a production of $3,125 \mathrm{~kg} / \mathrm{ha}$ from polyculture of gulsha (M. cavasius) with rajpunti (Barbodes gonionotus) and silver carp (Hypophthalmichthys molitrix) in earthen ponds.

Acknowledgement: This experiment conducted through the project "Field Validation of Selected High Valued Fish Culture Technologies for Maximizing Production (2018-19)" of Bangladesh Fisheries Research Institute, Mymensingh. 
PARVEZ CHOWDHURYet al.

\section{Literature Cited}

Ali, M.H., 1998. The potential of periphyton-based monoculture of a major carp, calibaush Labeo calbasu (Hamilton), MS Thesis, Department of Fisheries Management, Bangladesh Agricultural University, Mymensingh, Bangladesh, $37 \mathrm{p}$.

Ahmed, K., 1993. The effect of feed and fertilizers on carp polyculture in ponds. $\mathrm{PhD}$ dissertation, Department of Zoology, Dhaka University. 162 p.

Bhuiyan, B.R, 1970. Physico-chemical qualities of water of some ancient tanks in Sibsagar, Assam. Environ. Health, 12: 129-134.

Boyd, C.E, 1982. Water quality management for pond fish culture. Elsevier Sci. Publ. CO. Amsterdam-Oxford- New York. 318 p.

Chowdhury, P., M.Z. Hossain, M.S. Islam, A. Bhadra and M.S. Rahman, 2019. Production performance of pabda, gulsha and rohu in polyulture management. Bangladesh J. Fish. 31(2): 209.

Chowdhury, P., M.Z. Hossain, N.A. Raushon and M.S. Rahman, 2018. Effects of different amounts of organic fertilizers on growth and production of tilapia in monoculture. Int. J. Agril. Res. Innov. Tech. 18(2): 24-31.

DoF, 2019. Fisheries Yearbook of Bangladesh. Department of Fisheries, Ramna, Dhaka.

Hossain, M.A., S. M. Rahmatullah, M.S. Islam, A.K.M.A. Kabir, M.S. Islam and S. Dewan, 1997. Impact of chapila (Gudusia chapra Ham.) on growth of carps in polyculture. Bangladesh J. Fish. Res., 1(2): 19-23.

Kohinoor, A.H.M., M.A. Hossain and. M.G. Hussain, 1997. Semi-intensive culture and production cost of pabda (Ompok pabda) with rajpunti (Puntius gonionotus) and mirror carp (Cyprinus carpio var. specularis) in mini ponds. Bangladesh J. Zool. 254(2): 129133.

Kohinoor, A.H.M., M.L. Islam, M.A. Wahab and S.H. Thilsted, 1998. Effect of mola (Amblypharyngodon mola Ham.) on the growth and production of carps in polyculture. Bangladesh J. Fish. Res., 2(2): 119-126.

Kohinoor, A.H.M., M.A. Hossain and M.G. Hussain, 1997. Semi-intensive culture and production cost of pabda (Ompok pabda) with rajpunti (Puntius gonionotus) and mirror carp (Cyprinus carpio var. specularis) in mini ponds. Bangladesh J. Zool. 254(2):129-133.

Majumder, T.H., P. Chowdhury, M. Shahjahan and M.S. Rahamn, 2017. Effects of population density on growth and production of tilapia in monoculture. MS Thesis, Department of Fisheries Management, Bangladesh Agricultural University, Mymensingh, Bangladesh.

Mazid, M.A. 2009. Impacts of fish population density in the growth and production of carps in polyculture system. MS Thesis, Department of Fisheries Management, Bangladesh Agricultural University, Mymensingh, Bangladesh.

Paul, S., 1998. Comparison between carp polyculture system with silver carp, (Hypophthalmichthys molitrix) and with small indigenous fish mola, (Amblypharyngodon mola). MS Thesis, Department of Fisheries Management, Bangladesh Agricultural University, Mymensingh. 85 p.

Rahman, M.S., 1992. Water Quality Management in Aquaculture. BRAC Prokashana, Dhaka. $84 \mathrm{p}$.

Sarker, M.K.H., 2007. Impacts of duckweed powder as an ingredient of feed on production of Tilapia (Oreochromis niloticus). MS Thesis, Department of Fisheries Management, Bangladesh Agricultural University, Mymensingh. 87 p. 


\section{PRODUCTION OF PABDA AND GULSHA WITH ROHU IN POND}

Sharmin, F., M.S. Rahman, M. Shahjahan and P. Chowdhury, 2019. Study of growth and productions of tilapia (Oreochromis niloticus) on different population densities in monoculture. Int. J. Agril. Res. Innov. Tech. 9(2): 76-83.

Sultan, R., A.H.M. Kohinoor, M.S. Islam, M.G. Hussain, 1997. Comparative-studies on growth of fry of GIFT and existing strain of Nile Tilapia (Oreochromis niloticus). Bangladesh J. Fish. Res., 1: 25-30.

Swingle, H.S., 1967. Standardizations of chemical analyses for water and pond muds, FAO Fish Rep., 4: 397-421.

(Manuscript received 14 October 2020) 